\title{
Facial cellulitis caused by Giant parotid sialolith: a minimally invasive treatment for
}

\section{a rare occurrence}

Celulite facial causada por sialolito gigante de parótida: um tratamento minimamente invasivo para uma ocorrência rara

Celulitis facial causada por sialolito gigante de parotid: um tratamiento minimamente invasivo para uma ocorrência rara

Moacyr Tadeu Vicente Rodrigues ORCID: https://orcid.org/0000-0002-4951-5836 University of Campinas, Brazil E-mail: mtadeuvr@gmail.com

Filipe Ebenezer de Aguiar Schueng ORCID: https://orcid.org/0000-0002-8025-5710 São Lucas University Center, Brazil

E-mail: filipe_schueng@outlook.com

Bruno Coelho Mendes

ORCID: https://orcid.org/0000-0001-7896-8909 Sao Paulo State University, Brazil E-mail: brunoc.mnds@gmail.com José Marcelo Vargas Pinto

ORCID: https://orcid.org/0000-0002-1079-0785 Base Hospital of Porto Velho, Brazil E-mail: jmvp@bol.com.br

Fabrício Guimarães de Souza ORCID: https://orcid.org/0000-0002-4142-1114 João Paulo II Hospital. Rondônia State Government, Brazil

E-mail: fabricio.guimaraes@ outlook.com Cláudio Ferreira Nóia

ORCID: https://orcid.org/0000-0003-2336-6737 University of Campinas, Brazil E-mail: claudion@unicamp.br

\begin{abstract}
Sialolithiasis is a common disease that affects the major salivary glands and can occur at any age. Parotid glands are rarely involved and, even rarer are the cases of sialoliths larger than $10 \mathrm{~mm}$. This report presents the rare case of a giant parotid sialolith associated with facial cellulitis in a 75-year-old man. The treatment involved initially nonsurgical approach followed by a minimally invasive surgery to restore health and function. The treatment protocol was completely successful and proved effective in clinical and surgical management of giant parotid sialolith associated with facial cellulitis.
\end{abstract}

Keywords: Parotid gland; Salivary gland calculi; Cellulitis; Treatment protocol.

\section{Resumo}

A sialolitíase é uma doença comum que afeta as glândulas salivares maiores e pode ocorrer em qualquer idade. As glândulas parótidas raramente são envolvidas e, mais raros ainda são os casos de sialolitos acima de $10 \mathrm{~mm}$. Este relato apresenta o caso de um raro sialolito parotídeo gigante associado à celulite facial em um homem de 75 anos. $\mathrm{O}$ tratamento envolveu uma abordagem inicialmente não cirúrgica seguida por uma cirurgia minimamente invasiva para restaurar saúde e função. O protocolo de tratamento foi totalmente bem-sucedido e se mostrou eficaz no manejo clínico e cirúrgico do sialolito parotídeo gigante associado à celulite facial.

Palavras-chave: Glândula parótida; Sialolitíase; Celulite; Protocolo de tratamento.

\section{Resumen}

La sialolitiasis es una enfermedad común que afecta las glándulas salivales más grandes y puede ocurrir a cualquier edad. Las glándulas parótidas casi nunca están afectadas y, aún más raros, son los casos de sialolitos de más de 10 $\mathrm{mm}$. Este reporte presenta el caso de un sialolito parotídeo gigante raro asociado a celulitis facial en un hombre de 75 años. El tratamiento involvió un enfoque inicialmente no quirúrgico seguido de una cirugía mínimamente invasiva 
para restaurar la salud y la función. El protocolo de tratamiento fue totalmente exitoso y demostró ser efectivo en el manejo clínico y quirúrgico del sialolito parotídeo gigante asociado con celulitis facial.

Palavras-clave: Glándula parótida; Calculos de las glândulas salivares; Celulitis; Protocolo de tratamento.

\section{Introduction}

Sialolithiasis is a common disease that affects the major salivary glands. It is characterized by obstruction of salivary secretion by a calculus, commonly associated with swelling, pain and infection of the affected gland Bodner, 1993; Bodner, 1999).

Submandibular gland is the most affected gland (80\% to $95 \%$ ), whereas $5 \%$ to $20 \%$ are found in the parotid gland. The sublingual gland and the minor salivary glands are rarely affected (1\% to $2 \%)$. Sialoliths can occur at any age, but there is a peak incidence between the third and sixth decades and a male predilection is reported (Lustmann, Regev, \& Melamed, 1990; Bodner, 2002).

Sialoliths are mostly composed by calcium phosphate (hydroxyapatite) and also an organic matrix consisting of carbohydrate and amino acids. The mechanism of the formation of sialoliths is still poorly understood, although the $\mathrm{pH}$, mucin content, high $\mathrm{Ca}++$ concentration of the gland, salivary stagnation, a nidus and a precipitaion of salivary salts. Furthermore, the ascendant, snaky rout and against gravity long lenght of the Wharton's duct can also contribute, probably explaining the higher rate of occurrence in this gland. Infection, inflammation of the gland, or physical trauma to the duct or its orifice are also listed as predisposing factors (Bodner, 1993; Bodner, 2002; Guastaldi, da Silva, Troulis, \& Lahey, 2018).

Parotid glands are rarely involved and most often unilaterally, single and located within the ductal system (Ottaviani, Galli, Lucia, \& Ventura, 1997). The size of sialoliths may vary from less than less than $1 \mathrm{~mm}$ to a few centimeters (Bodner, 1999; Levy, Remine \& Devine; Iqbal, Murthy, \& Sharma, 1992; Kesse, Shehab, \& Courteney-Harris, 1998). Most of the parotid sialoliths are less than $10 \mathrm{~mm}$ in size, whereas giant parotid sialoliths (larger than $15 \mathrm{~mm}$ ) are quite rare. The giant Parotid sialoliths are also usually smaller than those in the submandibular gland (Lustmann et al, 1990; Bodner, 2002). The sialolith may eventually undergo migration and be expelled through the duct or through a cutaneous fistula (Brown, Cheah, \& Ha, 2016). Além disso as técnicas para exérese são variadas e podem considerer abordagem intrabucal ou extrabucal (Gillespie, 2018).

The present article is a report on an unusual giant parotid sialolith as a cause of facial cellulitis, its diagnosis and management.

\section{Methodology}

A descriptive and qualitative interventional study was carried out, in the format of a Case Report of a patient's followup during treatment. The epidemiological data and, history of the disease, were collected through the physical and electronic records, after authorization of the patient and signature of the Informed Consent, as (Brown et al, 2016).

\section{Case Report}

A 75-year-old man was referred to the emergency, with a two-week history of fever and a painful, diffuse tender swelling on the right side of the face (Figure 1). He reported intermittent episodes for 5 years of moderate to severe pain and swelling which settled spontaneously or with a course of oral antibiotics. He referred diabetes mellitus and systemic arterial hypertension, controlled by oral metformin and captopril, respectively. There was no history of tooth pain during all of this period, what would reinforce the diagnosis of a non-odontogenic cellulitis. 
Figure 1 - Diffuse swelling on the right midlle facial third.

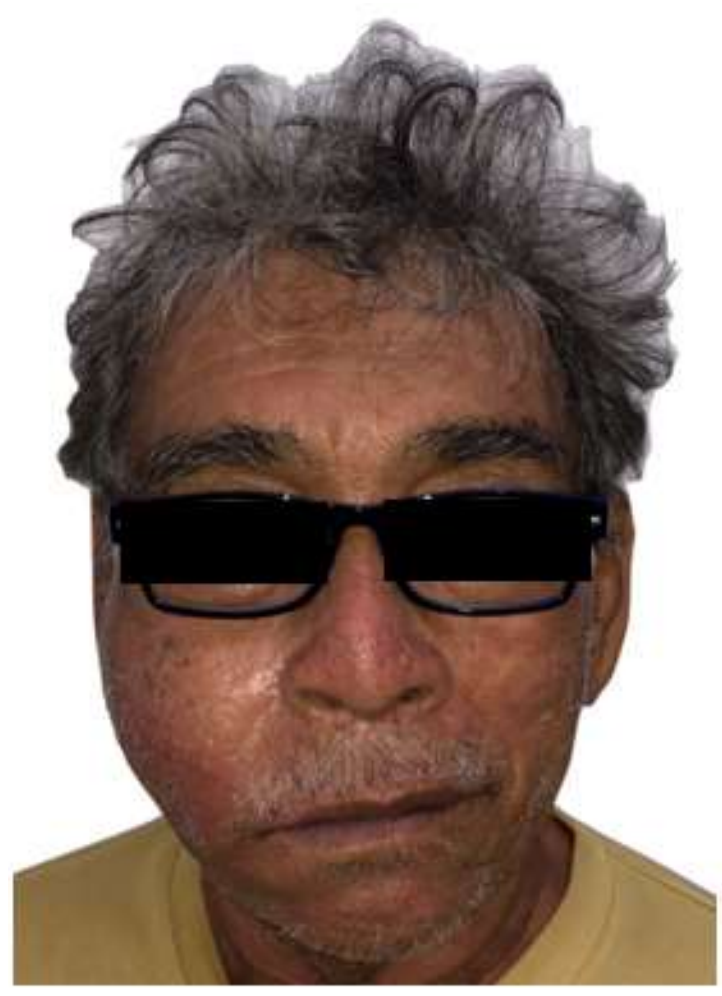

Source: Authors.

Upon inspection, there was a massive painful hyperemic hard swelling on the right parotid and buccal spaces, facial asymmetry, without facial nerve paralysis and purulent drainage. Oroscopy revealed trismus and reddish swelling on the right buccal mucosa as well as no odontogenic source of infection.

Computed tomography revealed a large oval hyperdense image in the buccal space, consistent with the diagnosis of sialolithiasis in the right Stensen's duct (Figure 2 and 3). 
Research, Society and Development, v. 10, n. 3, e58210313754, 2021

(CC BY 4.0) | ISSN 2525-3409 | DOI: http://dx.doi.org/10.33448/rsd-v10i3.13754

Figure 2 - Coronal view in computed tomography showing hyperdense oval image in swelled buccal space, suggestive of parotid sialolith on the right side.

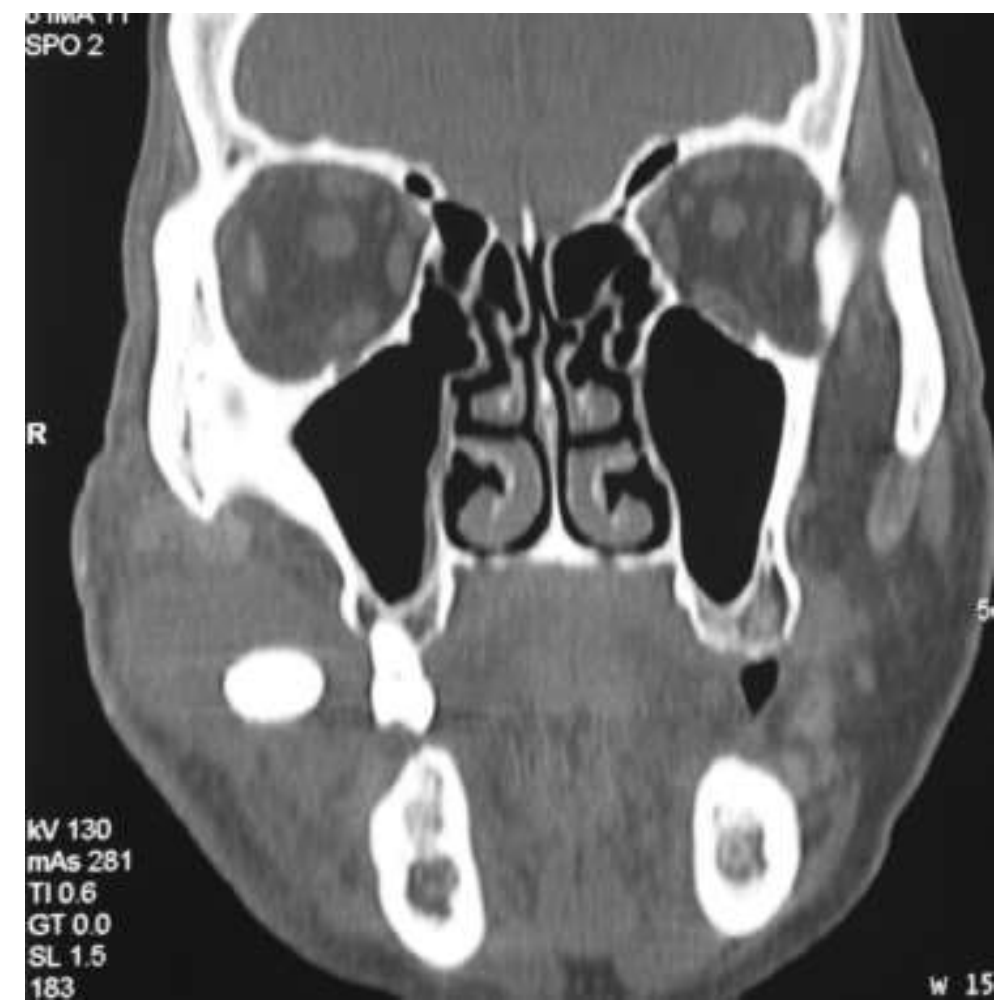

Source: Authors.

Figure 3 - Hyperdense oval image in buccal space, on the right side, in 3D CT image.

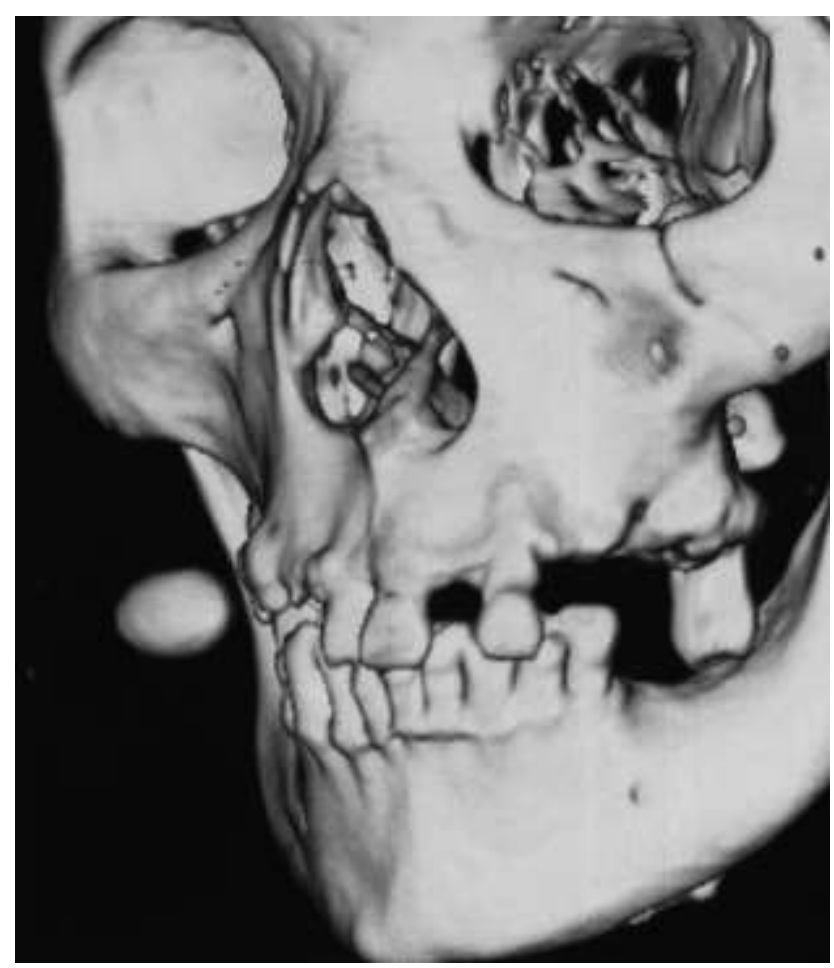

Source: Authors. 
Considering the patient`s clinical conditions, we opted for hospitalization and intravenous antibiotic therapy for initial control of infection and subsequent sialolith surgical removal. The antibiotic therapy consisted of intravenous ceftriaxon $(1 \mathrm{~g}$, twice a day), metronidazole (500 mg, three times a day) and gentamicin ( $80 \mathrm{mg}$, three times a day). After 5 days, the swelling, pain and trismus were better and the surgery was performed under general anesthesia (Figure 4).

Figure 4 - Clinical aspect after antibiotic therapy.

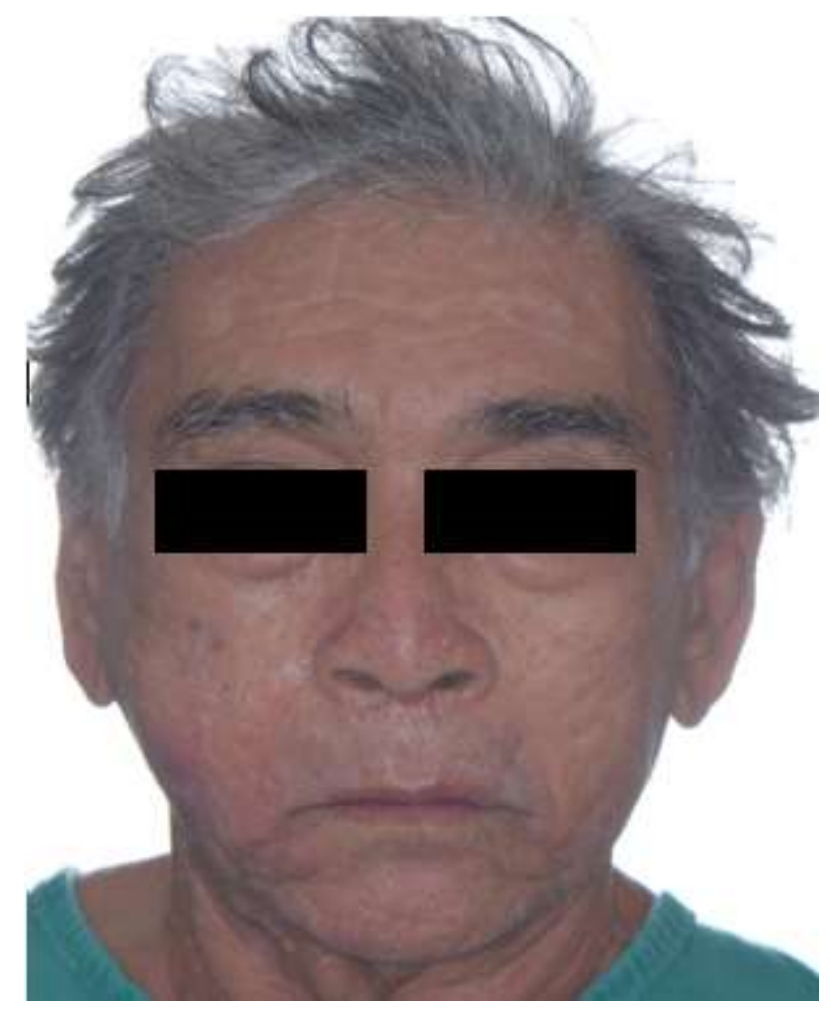

Source: Authors.

A $15 \mathrm{~mm}$ mucosal incision was done posterior to the duct orifice and blunt dissection was carried out towards the calculus (Figure 5). 
Research, Society and Development, v. 10, n. 3, e58210313754, 2021

(CC BY 4.0) | ISSN 2525-3409 | DOI: http://dx.doi.org/10.33448/rsd-v10i3.13754

Figure 5 - Sialolith removal by intraoral approach after incision and dissection.

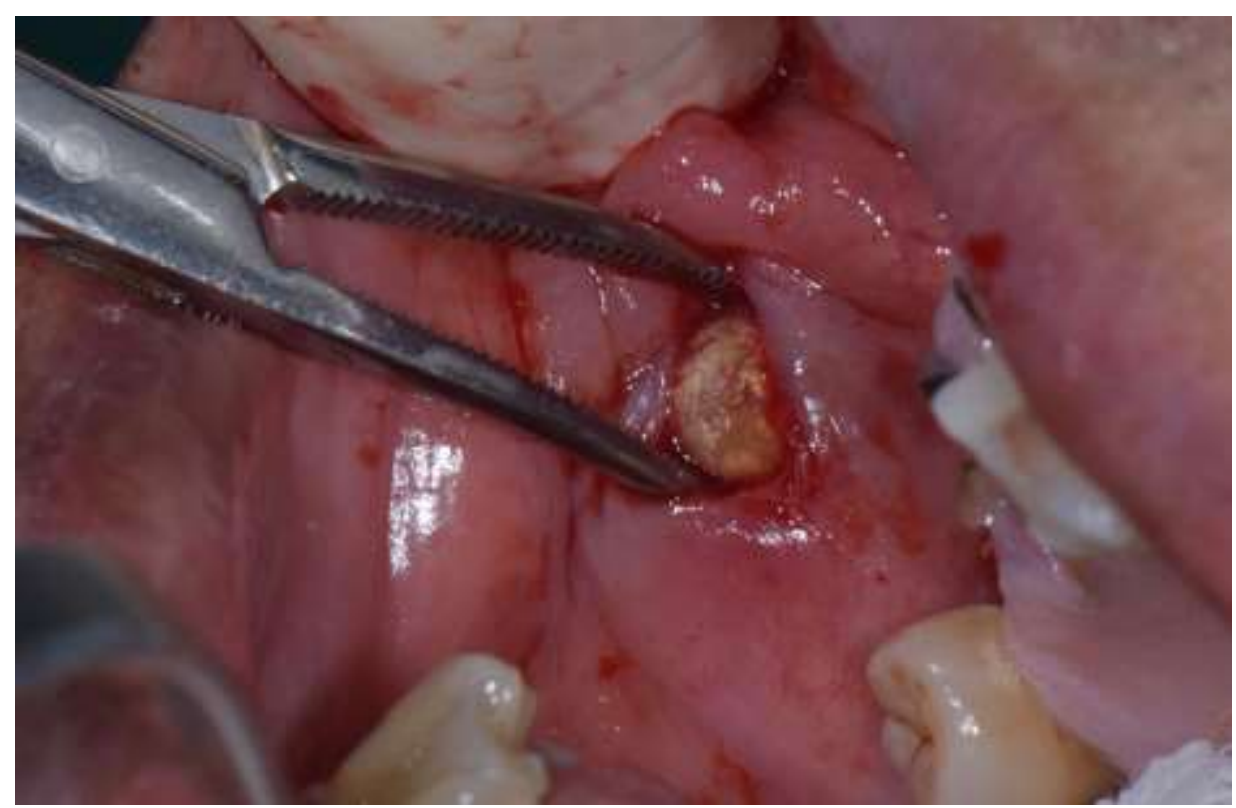

Source: Authors.

A small amount of purulent mucous saliva was discharged after reaching the Stensen`s duct surgically and the sialolith was removed afterwards. The sialolith measured 16 X $12 \mathrm{~mm}$ (Figure 6).

Figure 6 - Giant parotid sialolith (>15mm).

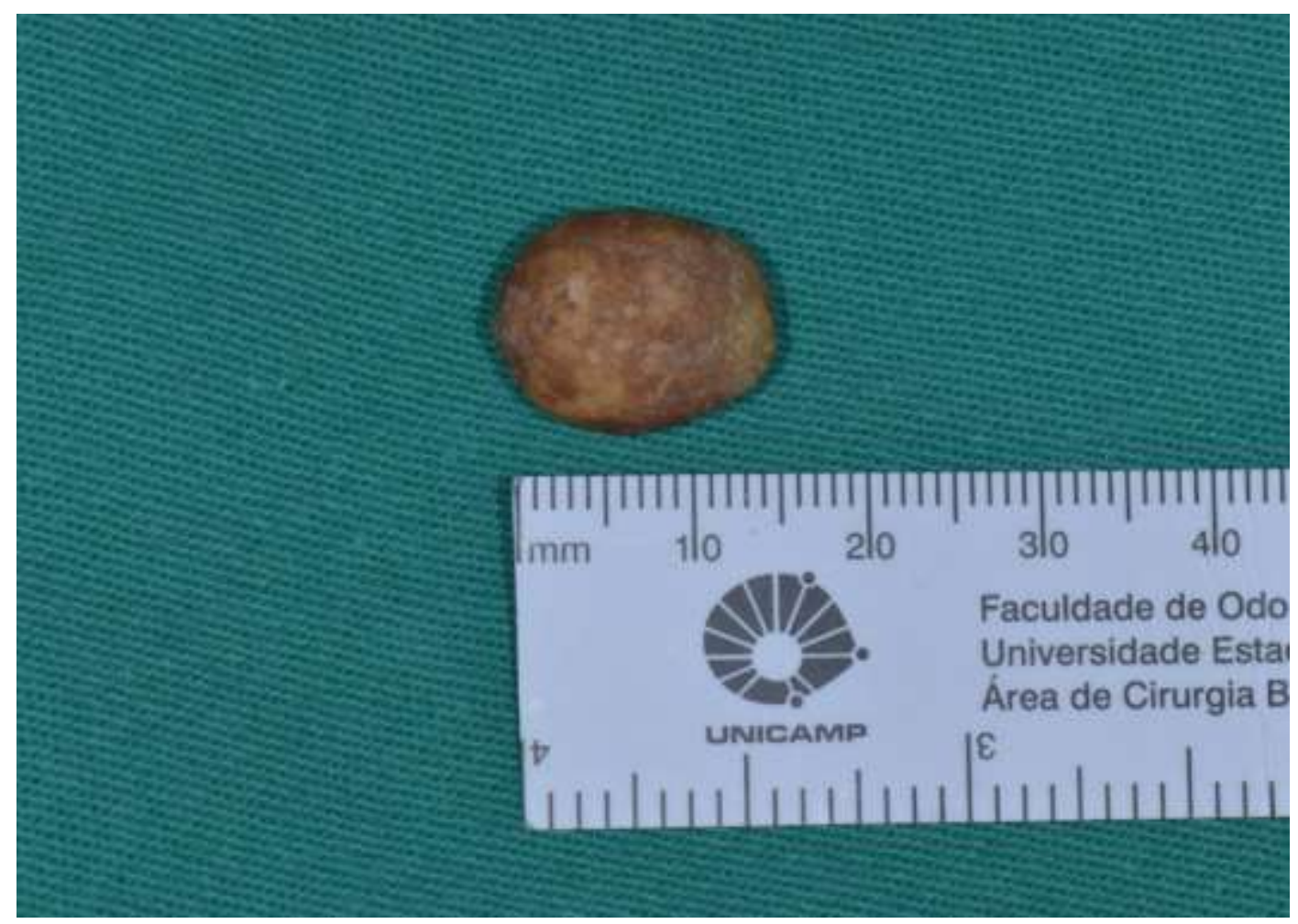

Source: Authors.

No sutures were applied to avoid complications (Figure 7). The recovery was uneventful (Figure 8). 
Research, Society and Development, v. 10, n. 3, e58210313754, 2021

(CC BY 4.0) | ISSN 2525-3409 | DOI: http://dx.doi.org/10.33448/rsd-v10i3.13754

Figure 7 - Final aspect after sialolith removal and hemostasis.



Source: Authors.

Figure 8 - Final clinical aspect after 2 months of treatment.

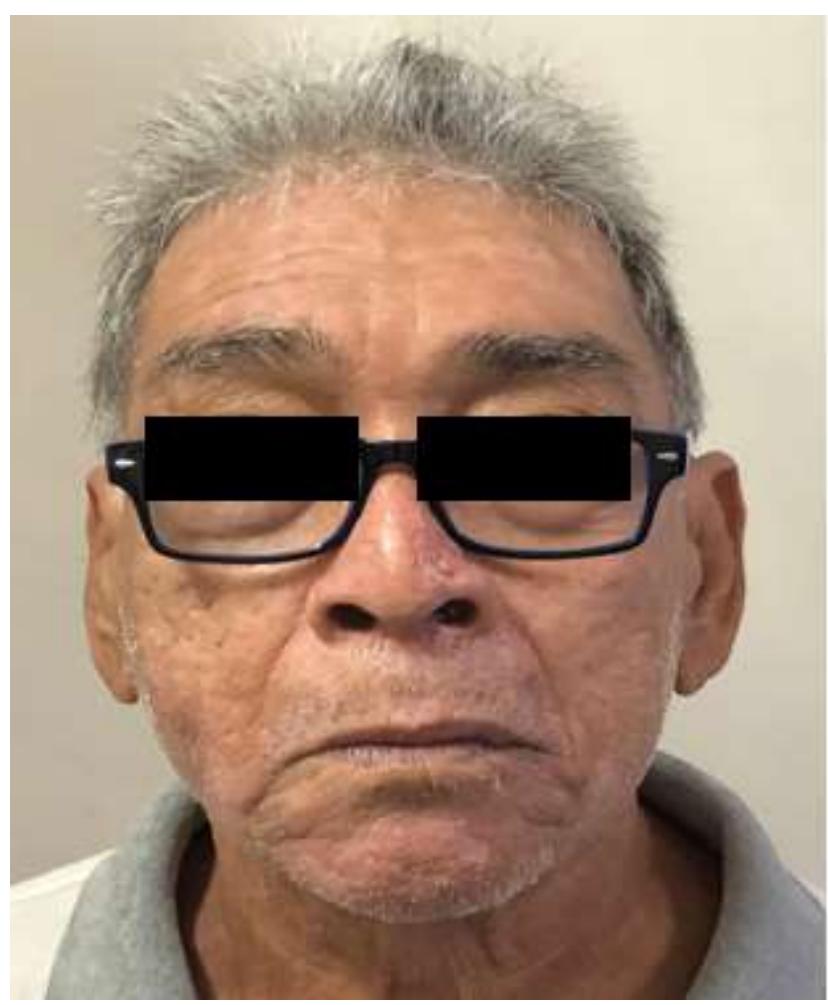

Source: Authors. 


\section{Discussion}

Parotid sialoliths are considered rare as compared to those of the submandibular gland. The presence of microcalculi in $80 \%$ of normal submandibular and only in $10 \%$ of normal parotid glands may explain the differences of sialoliths incidence in these two glands (Bodner, 1999; Epivatianos, \& Harrison, 1989).

The higher incidence of sialolithiasis in elderly patients may be due medication consumption that would reduce the secretory activity, modify electrolyte saliva concentrations and glycoprotein synthesis leading to structural deterioration of cell membranes of the salivary glands (Lustmann et al, 1990; Bodner, 2002; Bodner \& Gorsky, 1996).

This case is an acute exacerbation of a longstanding chronic asymptomatic parotid sialolithiasis, mimetizing an odontogenic cellulitis. The sialolith large size $(16 \times 12 \mathrm{~mm})$ indicates a rare giant parotid sialolith, one of the largest parotid sialolith ever reported.

Igbal et al. (1992) reported a parotid calculus measured 30 X 25 X 15 mm. Kesse et al. (1998) reported a giant parotid calculus measured $50 \mathrm{~mm}$ in length and $30 \mathrm{~mm}$ in its longest width, the largest parotid gland calculus ever reported.

Bodner (1999) reported another giant parotid calculus measured 25x13mm. Bodner (2002) showed that only 14 welldocumented cases of Giant salivary gland calculi (>15 mm) have been reported in the literature since 1942, involving submandibular and parotid gland, being a quite rare occurrence in the parotid gland with only 2 cases reported in that survey. The treatment objective of giant sialoliths, as for the standardsized stones, is restoration of normal salivary secretion. However, differential diagnosis is essential in cases of orofacial infections. Odontogenic infections usually present themselves as cellulitis. So the precise source of infection must be detected and the less invasive treatment as possible applied to avoid the morbidity caused by sialadenectomy, as usually required in cases of intraglandular sialoliths (Bodner, 2002).

\section{Conclusion}

In the case presented, the intraductal location and the favorable clinical evolution after antibiotic therapy avoided the need for extraoral drainage, sialedenectomy and other anti-aesthetic and invasive approaches, proving to be a successful treatment protocol for this rare occurence.

\section{References}

Bodner L. (1993). Salivary gland calculi: diagnostic imaging and surgical management. Compendium (Newtown, Pa.), 14(5), 572-586.

Bodner, L., \& Gorsky, M. (1996). Parotid gland secretion of the aging rat. Archives of gerontology and geriatrics, 22(1), 63-69. https://doi.org/10.1016/01674943(95)00678-8

Bodner L. (1999). Parotid sialolithiasis. The Journal of laryngology and otology, 113(3), 266-267. https://doi.org/10.1017/s0022215100143750.

Bodner L. (2002). Giant salivary gland calculi: diagnostic imaging and surgical management. Oral surgery, oral medicine, oral pathology, oral radiology, and endodontics, 94(3), 320-323.

Brown, K., Cheah, T., \& Ha, J. F. (2016). Spontaneous cutaneous extrusion of a parotid gland sialolith. BMJ case reports, 2016 , bcr2016214887. https://doi.org/10.1136/bcr-2016-214887

Epivatianos, A., \& Harrison, J. D. (1989). The presence of microcalculi in normal human submandibular and parotid salivary glands. Archives of oral biology, 34(4), 261-265. https://doi.org/10.1016/0003-9969(89)90066-6

Gillespie M. B. (2018). Combined Parotid Techniques. Atlas of the oral and maxillofacial surgery clinics of North America, 26(2), 133-143. https://doi.org/10.1016/j.cxom.2018.05.004

Guastaldi, F., da Silva, J., Troulis, M. J., \& Lahey, E. (2018). Surgical Retrieval of Parotid Stones. Atlas of the oral and maxillofacial surgery clinics of North America, 26(2), 105-110. https://doi.org/10.1016/j.cxom.2018.05.009

Iqbal, S. M., Murthy, J. G., \& Sharma, N. (1992). Giant parotid calculus--an unusual presentation. The Journal of laryngology and otology, $106(5)$, $446-447$. https://doi.org/10.1017/s0022215100119784. 
Research, Society and Development, v. 10, n. 3, e58210313754, 2021

(CC BY 4.0) | ISSN 2525-3409 | DOI: http://dx.doi.org/10.33448/rsd-v10i3.13754

Kesse, W. K., Shehab, Z. P., \& Courteney-Harris, R. (1998). A megalith of the parotid salivary gland. The Journal of laryngology and otology, 112(8), 784785. https://doi.org/10.1017/s0022215100141696

Levy, D. M., Remine, W. H., \& Devine, K. D. (1962). Salivary gland calculi. Pain, swelling associated with eating. JAMA, 181, 1115-1119. https://doi.org/10.1001/jama.1962.03050390017005.

Ottaviani, F., Galli, A., Lucia, M. B., \& Ventura, G. (1997). Bilateral parotid sialolithiasis in a patient with acquired immunodeficiency syndrome and immunoglobulin G multiple myeloma. Oral surgery, oral medicine, oral pathology, oral radiology, and endodontics, 83(5), 552-554. https://doi.org/10.1016/s1079-2104(97)90119-0. 